DOI: 10.20472/EFC.2021.015.010

\author{
VÁCLAV VYBÍHAL \\ University of Ss. Cyril and Methodius in Trnava, Slovakia \\ BARBORA BLAŠKOVÁ \\ University of Ss. Cyril and Methodius in Trnava, Slovakia
}

\title{
MOTIVATIONAL ASPECTS OF PROFESSIONAL TRAINING OF PUBLIC SECTOR EXPERTS
}

\begin{abstract}
:
Abstract:

Not only in economic theory, but also in social practice, it is evident that constantly increasing living standards and citizen's security levels in various health, social and other spheres of society are associated not only with increase in the amount of funds regarding public budgets' expenditures, but also with a rightful requirement for a certain education level of the public sector employees. The aim of this publication was to find out, identify, describe and evaluate motivation-al aspects of professional training of experts who are preparing to work in the public sector, to find out what motivates them, how they decide on what to study at university, how they imagine their post-gradual work will look like (including territory and charac-ter of a workplace) and how they evaluate their decision that they have chosen this field after a certain time. This issue opens the way for examining the specifics of professional training motivations, while its implementation can contribute to rectification and im-provement of the preparation of experts who are expected to meet very exacting re-quirements in the new economic conditions.

The database necessary for evaluation of the motivational aspects of professional train-ing of public sector experts was obtained based on our own survey in a form of a ques-tionnaire which was answered by students attending the Faculty of Social Sciences at the University of Ss. Cyril and Methodius in Trnava (Slovak Republic) in the winter term of academic year 2019/2020.

The decision to study at university unarguably belongs to fundamental life decisions. That is why it is possible to consider the given topic to be current. This decision is formed by a number of factors that can influence the student's approach to learning and his attitude in applying his knowledge and skills into practice.
\end{abstract}

\section{Keywords:}

Motivation of students, decision-making, professional training, questionnaire, universi-ty, Slovakia

JEL Classification: H52, J24, O15 


\section{Introduction}

Motivation of a human subject to fulfil objective requirements of the period as well as motivation to fulfil personal ambitions can be significantly formed during the professional training already. This is the case in the whole society, thus in the public sector as well. Therefore, it is necessary to monitor and evaluate, among other things, the spectrum of causal and randomly formed connections of the decision-making process for university studies and subsequent implementation of the professional training in social practice. Opening the way to examining the specifics of the motivation of professional training of public sector experts as a follow-up to future practical application can contribute to rectification and improvement of the preparation of experts who are in today's society expected to meet very exacting requirements.

Following a series of economic reforms, decentralization has deepened in the Slovak Republic (European Union). A new young generation is taking up functions in the public sector, with the share of university-educated experts in the total workforce starting to be higher than in the private sector. This is evident not only in the state sector, but also in the area of municipalities. The number of $\mathrm{PhD}$ graduates in the workforce structure of central government bodies, especially ministries, where they often hold managerial and executive positions is increasing. Almost all regional governors operating on higher territorial units (regions) have higher education and based on our own findings, more than $70 \%$ of mayors (of towns and municipalities) are university graduates, mostly of humanitarian and economic orientation. Also, a number of MA and $\mathrm{PhD}$ graduates of the University of Ss. Cyril and Methodius have been employed in the positions mentioned above.

Since the cited faculty educates and forms the students primarily for the needs of the private sector and its dominant fields deal with public administration and social politics, we decided to carry out a survey of motivational aspects concerning professional training of potential experts.

The aim of this publication was to find out, identify, describe and evaluate motivational aspects of professional training of experts who are preparing to work in the public sector, to find out what motivates them, how they decide on what to study at university, how they imagine their post-gradual work will look like (including territory and character of a workplace) and how they evaluate their decision that they have chosen this field after a certain time. We want to use the achieved knowledge to improve professional training of future public sector employees.

\section{Material and Methodology}

The initial database needed for the fulfilment of the publication's aim was represented by the results obtained by our own survey. This survey in form of questionnaires was based on absolute voluntariness of its respondents of all bachelor, master and doctoral studies at the Faculty of Social Studies of the University of Ss. Cyril and Methodius in Trnava (Slovak 
Republic, European Union). The examined sample consisted of 135 respondents, of which $63 \%$ were female students and $37 \%$ were male students. In terms of the study form, $95.5 \%$ of the respondents study in a full-time mode and $4.5 \%$ in a part-time (external) mode. The number of respondents is in accordance with the methodology used for determining the number of respondents in demographic researches, published by Vybíhal and Kubíček (1974).

In terms of the study programme's structure, the representation of respondents studying in the area of public administration played the decisive role $(42.2 \%$ of them study Public Administration, 40\% study Management and Economy of Public Administration). Another $11.9 \%$ of respondents study Social Services and Counselling and 5.9\% study European Studies and Politics. Permanent residence (based on regions) of the respondents was represented as follows: Trnava region 43.8\%, Trenčín region 14.8\%, Bratislava region $11.1 \%$, Žilina region 9.6\%, Banská Bystrica region 8.1\%, Prešov region 5.2\%, Nitra region $4.4 \%$ and Košice region 3.0\%. It can be stated that the students of the faculty come from all Slovak regions, while a significant proportion of the students (43.8\%) live in a region of the university's seat.

The methodological approach of this publication is based on a defined set of questions which were asked via a questionnaire, in which the issue can be divided into several groups.

The first group consists of questions used to identify the respondents in terms of gender, study programme, form of study, degree (bachelor's, master's and doctoral), year of study and place of permanent residence. The second group of questions is related to the possibility of clarifying the reasons for entering the given study programme and satisfaction with the respondent's decision from today's point of view. The third group includes questions focused on the possibilities of finding a job after graduation from the economic point of view, questions focused on the study programme's difficulty as well as on the preference of leisure time activities, and, last but not least, it contains an evaluation of teachers and their mutual pedagogical-scientific relationship towards students as well as an evaluation of the source of the most common study problems during the studies.

The partial answers of the respondents were expressed in relative frequencies and summarized as a whole, also in terms of study degree and sex, which allowed us to do a comparative analysis.

\section{Results}

As a follow-up to the methodology of this work based on processing and evaluation of frequencies in the respondents' answers to the sets of questions, it is possible to divide the obtained results of the survey into several specific but interrelated units.

The data presented in table no. 1 show that the decisive motives for applying for a particular study programme of the given faculty and university are represented mainly by 
the facts that there is no need to take entrance examinations and the faculty is relatively accessible from the place of respondent's permanent residence, with a significant proportion of respondents taking also recommendations from friends, acquaintances or the programme's graduates into consideration. The data presented in table no. 2 show that the fact that it is not necessary to take entrance examinations is for female students (43.5\%) more important factor influencing their decision to study at university than for male students (32.7\%). In contrast to men, female students have also a stronger link to the faculty's availability from the place of residence as well as to the place of the faculty's seat.

The table also displays an interesting and perhaps surprising fact that the influence of mass media and a personal visit during the Open Day play almost no role in the motivation of respondent's decision to study in a particular programme. In case of the mass media, it is possible that the citizens' negative perception of many mass media in the Slovak Republic may play an important role. As for the Open Day, the findings are surprising in particular because universities and faculties pay significant attention to the quality of Open Day visits as well as to its presentation in the media, with the majority of universities hoping for much better results arising from this event than it is in reality.

Table 1: Main motives influencing the decision to enroll in a particular study programme (respondents marked a maximum of 3 reasons)

\begin{tabular}{|c|l|c|c|}
\hline No. & The motive of respondent's decision & $\begin{array}{c}\text { Absolute } \\
\text { frequency }\end{array}$ & $\begin{array}{c}\text { Relative } \\
\text { frequency (\%) }\end{array}$ \\
\hline 1 & $\begin{array}{l}\text { There was no need to take entrance } \\
\text { examinations }\end{array}$ & 53 & 39.3 \\
\hline 2 & Faculty's availability from the place of residence & 45 & 33.3 \\
\hline 3 & $\begin{array}{l}\text { Recommendations from friends and } \\
\text { acquaintances }\end{array}$ & 43 & 31.9 \\
\hline 4 & I just wanted to get a relevant title & 31 & 23.0 \\
\hline 5 & Long-time interest in the given programme & 28 & 20.7 \\
\hline 6 & Perspective of the programme in the future & 22 & 16.3 \\
\hline 7 & The seat of the faculty & 20 & 14.8 \\
\hline 8 & Influence of parents and family & 15 & 11.1 \\
\hline 9 & Personal visit during the Open Day & 13 & 9.6 \\
\hline 10 & I was not accepted to any other faculty & 5 & 9.6 \\
\hline 11 & Influence of mass media & 3 & 3.7 \\
\hline 12 & Recommendations from teachers & 2.2 \\
\hline
\end{tabular}

Note: the frequencies of answers are listed in descending order.

Source: the results of our own survey.

Approximately one fifth of the students have a long-time interest in the study programme and see perspective of the programme regarding future possible employment in social practice, with men reporting significantly higher long-time interest in the given programme than women.

Surprisingly, the influence of parents and family is relatively low (11.1\%). Another certain, though not decisive motive is that the respondent was not accepted to the faculty of his 
preferential choice. Most often it included faculties with a significant excess demand (over supply).

We can say that almost a quarter of the respondents are motivated to study in higher education for the purpose of getting a relevant title. It is necessary to find out why this is the case and carry out further research. It can be assumed that higher education is needed in order to hold a professional position at majority of posts in the public administration, speaking not only about central state bodies, but also about regions and bigger municipalities. Chairmen of higher territorial units and $72 \%$ of mayors in the Slovak Republic have higher education as well.

Table 2: The difference between answers of male and female students about the main motives influencing the decision to enroll in a particular study programme (respondents marked a maximum of 3 reasons) - relative frequency in \%

\begin{tabular}{|r|l|c|c|}
\hline No. & The motive of respondent's decision & $\begin{array}{c}\text { Men } \\
\mathbf{( \% )}\end{array}$ & Women (\%) \\
\hline 1 & There was no need to do entrance examinations & 32.7 & 43.5 \\
\hline 2 & Faculty's availability from the place of residence & 28.5 & 36.5 \\
\hline 3 & $\begin{array}{l}\text { Recommendations from friends and } \\
\text { acquaintances }\end{array}$ & 30.0 & 32.9 \\
\hline 4 & Wanting to get a relevant title & 23.5 & 22.4 \\
\hline 5 & Long-time interest in the given programme & 32.0 & 14.1 \\
\hline 6 & Perspective of the programme in the future & 13.7 & 17.6 \\
\hline 7 & The seat of the faculty & 4.8 & 17.6 \\
\hline 8 & Influence of parents and family & 14.0 & 9.4 \\
\hline 9 & Personal visit during the Open Day & 9.4 & 9.4 \\
\hline 10 & Not being accepted to any other faculty & 8.0 & 10.6 \\
\hline 11 & Influence of mass media & 2.0 & 4.7 \\
\hline 12 & Recommendations from teachers & 0 & 3.5 \\
\hline
\end{tabular}

Source: the results of our own survey.

The issue dealing with the motives influencing a decision to enroll in a particular study programme is directly followed by questions connected to a feeling whether a person would decide to study in the given programme at the faculty again (after his current experience). The respondents' opinions on the suitability of the study field are displayed in table no. 3. The answers reflect, among other things, a level of satisfaction of respondents' original ideas about the effectiveness and content of the selected studies at the given faculty.

Table 3: Relative frequency of respondents' views on the suitability of the chosen study field (in \%)

\begin{tabular}{|l|l|r|r|c|}
\hline No. & \multicolumn{1}{|c|}{ Verification of the decision } & In total & Men & Women \\
\hline 1 & To study in the same programme at FSS & 46.7 & 48.1 & 45.9 \\
\hline 2 & To study in another programme at FSS & 3.0 & 6.0 & 1.2 \\
\hline 3 & To study at a different faculty of UCM & 10.4 & 14.2 & 8.2 \\
\hline 4 & To study at a different university in Slovakia & 22.1 & 10.0 & 29.4 \\
\hline 5 & To study abroad & 8.9 & 10.0 & 8.2 \\
\hline
\end{tabular}




\begin{tabular}{|l|l|r|r|r|}
\hline 6 & Not to study at university & 8.9 & 11.7 & 7.1 \\
\hline 7 & In total & 100.0 & 100.0 & 100.0 \\
\hline
\end{tabular}

Source: the results our own survey.

The data in table no. 3 show that $46.7 \%$ of the respondents would decide to study in the same programme of the same faculty and university again, with almost no difference between the men's and the women's group, even though men are slightly more satisfied with the chosen programme, faculty and university. Only 3\% of the respondents would prefer to study in a different programme at the same faculty and $10.4 \%$ of the respondents would prefer to study at a different faculty of the same university. From the first three answers (No. 1, 2, 3) shown in the table, it is clear, that men have a stronger bond to their university when compared to women. It is also important to note that $22.1 \%$ of the respondents (predominantly women) would revoke their original decision and rather study at a different university in Slovakia. The respondents' interest in studying abroad is minimal (8.9\%). When assessing the suitability of the chosen higher education studies, some respondents stated that they would prefer not to study at university at all. It possibly includes a group of students who do not have the prerequisites for higher education studies with regard to their learning outcomes, or their opinion is formed by other factors which may have various causes, or the studies are too difficult for them.

It can be positively stated that respondents of a given study programme solve partial nonfulfilment of their ideas about the studies in an active way, which means that they are interested either in a different study programme at the same faculty (3.0\%), in a different faculty of the same university (10.4\%), in a different university $(22.1 \%)$ or in studying abroad (8.9\%). Only $8.9 \%$ of all the respondents give up on higher education, as they would not like to study at university at all.

From a sociological point of view, respondents' opinions on the suitability of the chosen study field were probably shaped by the degree of satisfaction of their original ideas about the effectiveness and content of the studies. Last but not least, their opinions might be evoked by their personal approach to evaluation of the study demands, or by gradually formed ideas about the possibility of implementation of their professional training into practice.

The data in table no. 4 show that respondents' opinions regarding their experience with studying at the Faculty of Social Sciences (FSS) are related to the issue of the suitability of the chosen study programme as well.

Table 4: Relative frequency of respondents' opinions on the level of the fulfilment of their expectations based on their current study experience (\%)

\begin{tabular}{|c|l|c|c|c|}
\hline No. & $\begin{array}{c}\text { Level of the fulfilment of } \\
\text { expectations }\end{array}$ & In total & Men & Women \\
\hline 1 & Definitely yes & 12.6 & 16.1 & 10.6 \\
\hline 2 & Rather yes & 63.0 & 60.0 & 64.7 \\
\hline 3 & Rather no & 20.7 & 17.9 & 22.4 \\
\hline 4 & Definitely no & 3.7 & 6.0 & 2.3 \\
\hline
\end{tabular}




\begin{tabular}{|l|l|l|l|l|}
\hline 5 & In total & 100.0 & 100.0 & 100.0 \\
\hline
\end{tabular}

Source: the results of our own survey.

The data in table no. 4 show that $75.6 \%$ of the respondents stated that the study experience has met their expectations, while $24.4 \%$ stated that it has not met their expectations, which de facto corresponds with students' opinions on the suitability of the chosen study programme. Speaking of whether the studies are interesting (especially in terms of structure of subjects and their content), respondents' predominant opinion is that the studies partially meet their expectations, as seen in table no. 5 .

Table 5: Relative frequency of respondents' opinions on whether the studies are interesting or meet respondents' previous ideas about the studies (\%)

\begin{tabular}{|l|l|r|c|c|}
\hline No. & The studies are & $\begin{array}{c}\text { In } \\
\text { total }\end{array}$ & Men & Women \\
\hline 1 & Very interesting (meet the expectations) & 18.5 & 26.0 & 14.1 \\
\hline 2 & $\begin{array}{l}\text { Averagely interesting (partially meet the } \\
\text { expectations) }\end{array}$ & 77.1 & 68.1 & 82.4 \\
\hline 3 & Not interesting (does not meet the expectations) & 4.4 & 5.9 & 3.5 \\
\hline 4 & In total & 100.0 & 100.0 & 100.0 \\
\hline
\end{tabular}

Source: the results of our own survey.

A significant proportion of the respondents (77.1\%) stated that the studies are averagely interesting, with a higher percentage of women (82.4\%) than men (68.1\%), which shows that the studies meet their expectations only partially. $18.5 \%$ of the respondents claim that the studies meet their expectation completely, while it is evident that men consider the studies to be more interesting (thus meet their expectations) than women $(26.0 \%$ and $14.1 \%$ respectively). In this context, however, it is necessary to mention that the results of previous surveys show that when deciding, respondents often make decision in favour of the average option (because of psychological reasons). This is also the case in table no. 6 which shows answers to the question regarding respondents' opinions on the difficulty of the studies.

Table 6: Relative frequency of respondents' opinions on the level of studies' difficulty (\%)

\begin{tabular}{|l|l|c|c|c|}
\hline No. & Degree of difficulty & In total & Men & Women \\
\hline 1 & Extremely difficult & 2.2 & 6.0 & 0 \\
\hline 2 & Very difficult & 10.4 & 12.2 & 9.4 \\
\hline 3 & Averagely difficult & 80.0 & 76.0 & 82.4 \\
\hline 4 & Less difficult & 7.4 & 5.8 & 8.2 \\
\hline 5 & Very easy & 0 & 0 & 0 \\
\hline 6 & In total & 100.0 & 100.0 & 100.0 \\
\hline
\end{tabular}

Source: the results of our own survey.

When speaking about the studies' difficulty, it is possible to mention how busy the respondents feel during the studies. The majority of students $(71.6 \%)$ stated that they feel to be averagely busy (table no. 7). 
Table 7: Relative frequency of respondents' opinions on how busy they are during the studies (\%)

\begin{tabular}{|l|l|c|c|c|}
\hline No. & During the studies I feel & In total & Men & Women \\
\hline 1 & Busy & 9.0 & 18.1 & 4.7 \\
\hline 2 & Averagely busy & 71.6 & 54.0 & 81.2 \\
\hline 3 & I have some reserves & 17.2 & 27.9 & 10.5 \\
\hline 4 & Not busy & 2.2 & 0 & 3.6 \\
\hline 5 & In total & 100.0 & 100.0 & 100,0 \\
\hline
\end{tabular}

Source: the results of our own survey.

It can be stated that the issue of the suitability of the chosen studies, fulfilment of the expectations about the studies and difficulty of the studies is also connected to the fact that a student might have financial, family, personal, health, accommodation or other problems during his studies, or he does not like the organization of the studies, or he still has unsuitable habits from high school. Then, it is important to detect the sources of the most common problems during the studies (table no. 8).

Table 8: Relative frequency of the sources of most common problems during the studies (\%)

\begin{tabular}{|r|l|r|c|c|}
\hline No. & $\begin{array}{l}\text { The sources of most common problems during the } \\
\text { studies come from }\end{array}$ & $\begin{array}{c}\text { In } \\
\text { total }\end{array}$ & Men & Women \\
\hline 1 & High school studies & 9,7 & 8,2 & 10,6 \\
\hline 2 & $\begin{array}{l}\text { Organization of the studies at university (learning, } \\
\text { examinations) }\end{array}$ & 36,3 & 28,0 & 41,2 \\
\hline 3 & Accommodation conditions & 5,2 & 5,9 & 14,7 \\
\hline 4 & Lack of finances & 5,9 & 5,9 & 5,9 \\
\hline 5 & Conflicts with teachers & 2,2 & 4,0 & 1,2 \\
\hline 6 & Conflicts between students & 0,7 & 0 & 1,2 \\
\hline 7 & Family issues & 2,2 & 5,9 & 0 \\
\hline 8 & Health issues & 4,4 & 3,9 & 4,7 \\
\hline 9 & Other issues & 6,7 & 8,2 & 5,9 \\
\hline 10 & I do not have any problems & 26,7 & 30,0 & 24,7 \\
\hline 11 & In total & 100,0 & 100,0 & 100,0 \\
\hline
\end{tabular}

Source: the results of our own survey.

Approximately one third of the students report organization of the studies at university as the most common source of study problems. It is problematic especially for bachelordegree students because of a transition from high school to university, where different methods of learning, timetables, frequency of examinations and other criteria are used. Among master students, this source of study problems is less frequent.

The overall success in the studying field and students' opinions are to some extent also shaped by activities which are important for the respondent at the time of his studies. Since students usually have several activities, we asked them to mark a maximum of 3 crucial activities which they have been pursuing during their studies (table no. 9). 
Table 9: Relative frequency of respondents' opinions on the decisive leisure time activities during the studies (\%) - respondents marked a maximum of 3 options

\begin{tabular}{|c|c|c|c|c|}
\hline No. & Decisive leisure time activities during the studies & $\begin{array}{l}\text { In } \\
\text { total }\end{array}$ & Men & Women \\
\hline 1 & A trip to nature & 33.3 & 32.0 & 34.1 \\
\hline 2 & Culture (cinema, theatre, museum, etc.) & 31.1 & 24.1 & 35.3 \\
\hline 3 & $\begin{array}{l}\text { Computer activities (Internet, Facebook, Instagram, } \\
\text { etc.) }\end{array}$ & 31.1 & 43.9 & 23.5 \\
\hline 4 & Activities on mobile phones, tablets, etc. & 22.2 & 22.2 & 22.3 \\
\hline 5 & Dancing & 2.2 & 0.0 & 3.5 \\
\hline 6 & Sport & 40.7 & 56.2 & 31.8 \\
\hline 7 & Intimate activities & 17.8 & 26.0 & 12.9 \\
\hline 8 & Visiting a restaurant & 12.6 & 11.7 & 12.9 \\
\hline 9 & Watching TV and listening to radio & 9.6 & 6.0 & 11.8 \\
\hline 10 & Hobbies (not included in the previous activities) & 29.6 & 54.3 & 31.8 \\
\hline 11 & Other activities & 19.3 & 28.0 & 16.5 \\
\hline
\end{tabular}

Source: the results of our own survey.

Leisure time activities play a significant role during the studies. Evaluation of these activities from various perspectives is very difficult and questionable at the same time. One could say that leisure time and the way it is spent is the measure of human wealth. The respondents have to dedicate a part of their leisure time to personal hygiene, sleep and rest, as well. Taking age groups into consideration, it is expected that young people will prefer active fun to passive fun. Since the development of society is moving forward relatively quickly, the structure and extent of leisure time activities within individual generations and within the same generation are changing.

The data in table no. 9 show that the majority of respondents prefer active leisure time activities (sport, trips to nature, intimate activities and hobbies). Activities associated with modern development of society (activities on computer, mobile phone, etc.) are also significant. In terms of passive fun, culture (cinema, museum) plays predominant role, while other passive leisure activities, such as watching television, listening to radio or visiting a restaurant, are receding. Significant differences can be seen between men and women, as women prefer passive activities (cinema, theatre, museum, watching television, listening to radio, visiting a restaurant). In contrast to women, men prefer activities on a computer, sport, intimate activities and hobbies. Representation of activities on a mobile phone is almost the same among men and women.

Spending the leisure time actively (or passively) may be related to the fact whether a person spend his leisure time alone or with other people. The answers to this question are displayed in table no. 10.

The data in table no. 10 show that opinions of men and women on this topic are quite different. While men spend their leisure time in a balance between spending time alone and with other people, women incline to spending leisure time in a small group of people, which is quite natural. 
Table 10: Relative frequency of respondents' opinions on leisure time spending during the studies in terms of personal radius (\%)

\begin{tabular}{|l|l|c|c|c|}
\hline No. & I spend the leisure time during the studies & In total & Men & Women \\
\hline 1 & Alone & 14.8 & 19.9 & 11.8 \\
\hline 2 & In a pair & 27.4 & 22.1 & 30.6 \\
\hline 3 & In a small group (max. 6 people including myself) & 46.7 & 34.0 & 54.1 \\
\hline 4 & In a bigger group (7 or more people) & 11.1 & 24.0 & 3.5 \\
\hline 6 & In total & 100.0 & 100.0 & 100.0 \\
\hline
\end{tabular}

Source: the results of our own survey.

From a sociological point of view, it is also necessary to evaluate the relation between motivation to study at university, leisure time spending and preference of certain leisure time activities, and gradually formed ideas about the possibility of implementation of their professional training in practice. With regard to this fact, the next part of this publication encompasses the findings arising from the respondents' opinions on their future employment and using their knowledge in practice.

First of all, the respondents commented on whether the studies play an important role in using their experience in practice (as seen in table no. 11).

Table 11: Relative frequency of respondents' opinions on the importance of the studies for future implementation into practice (\%)

\begin{tabular}{|l|l|r|r|r|}
\hline No. & $\begin{array}{l}\text { The role of studies is very important for } \\
\text { further application in practice }\end{array}$ & In total & Men & Women \\
\hline 1 & Definitely yes & 40.0 & 50.0 & 34.1 \\
\hline 2 & Rather yes & 39.2 & 34.0 & 42.4 \\
\hline 3 & Rather no & 17.8 & 10.2 & 22.4 \\
\hline 4 & Definitely no & 3.0 & 5.8 & 1.1 \\
\hline 6 & In total & 100.0 & 100.0 & 100.0 \\
\hline
\end{tabular}

Source: the results of our own survey.

It is evident that according to the respondents, the role of studies is very important for further application in practice (79.2\%), especially for men (84\%). This is also an important knowledge when evaluating how well the respondent's expectations about the studies have been met.

Especially in the last year of bachelor and master studies, the respondents begin to form an idea of what they would like to do after a successful graduation and completion of their current degree (table no. 12).

Within the preference of a working activity after a successful graduation, approximately one third of the respondents stated the possibility of being an employee in the public sector, which corresponds with the professional focus of the programme in which the respondents are studying. A significant proportion of them wants to continue in their studies (30.4\%). They are predominantly students ending their bachelor's degree who wish to carry on their studies at a master's degree, while approximately $3 \%$ of masterdegree students intend to continue their studies at a doctoral degree. 
The respondents showed no interest in working in education which is financially unattractive (3.0\%), nor in the private sector (7.4\%). In contrast to women $(10.6 \%)$, men are more likely to carry on a business $(26.3 \%)$.

Table 12: Relative frequency of respondents' opinions on the preference of working activities after successful graduation (\%)

\begin{tabular}{|r|l|c|c|c|}
\hline No. & $\begin{array}{l}\text { After graduation from my current studies I want } \\
\text { to }\end{array}$ & $\begin{array}{c}\text { In } \\
\text { total }\end{array}$ & Men & Women \\
\hline 1 & Continue in follow-up studies in Slovakia & 27.4 & 32.0 & 24.7 \\
\hline 2 & Study abroad & 3.0 & 6.0 & 1.2 \\
\hline 3 & Be employed in education & 3.0 & 10.0 & 4.7 \\
\hline 4 & Be employed in public sector (outside education) & 28.1 & 20.0 & 32.9 \\
\hline 5 & Be employed in private sector & 7.4 & 0 & 11.8 \\
\hline 6 & Have a career in politics & 5.9 & 7.9 & 4.7 \\
\hline 7 & Carry on business as a natural person & 5.9 & 10.1 & 3.5 \\
\hline 8 & Start a business and carry on as a legal person & 10.4 & 16.2 & 7.1 \\
\hline 9 & Work or carry on business abroad & 8.9 & 7.8 & 9.4 \\
\hline 10 & In total & 100.0 & 100.0 & 100.0 \\
\hline
\end{tabular}

Source: the results of our own survey.

The respondents' interest in the character of the future workplace is largely determined by a number of objective and subjective factors which are also related to the preference of the place of their employment, or relations between psychosocial and emotional aspects of their lives which significantly shape their individual awareness.

\section{Conclusion and discussion}

Not only private sector, but also public sector plays an important role in countries with developed national economy. Its mission is primarily to prevent and solve the consequences of market failure in economic and social development. Public sector of a modern economy must be organized in a way that it respects individual freedom and at the same time is able to maintain and improve justice in social development, thus increase citizens' level of satisfaction.

As people's living standards increase, public budget expenditures increase (in accordance with the Wagner's law) and the level of state security in various social, health, cultural, sport and other spheres of life increases as well. This fact, among other things, creates a demand for increase in the level of education, especially in the public sector. Because of this and other reasons, we used analytical-synthetic methods and simple mathematicalstatistical methods to examine the motivational aspects of professional training of public sector experts, their motivations for choosing a particular study programme at university, their ideas and expectations about their future employment and their evaluation of suitability of their choice. Examining the specifics of motivation of professional training can significantly contribute to rectification and improvement of preparation of experts who are expected to meet very exacting requirements in the new economic conditions. 
Motivation is a phenomenon that often becomes the initiator of the level of human performance and pursues a specific goal which is the final phase of motivation. However, when deciding about higher education, the motivation of a young person might be accompanied by a certain level of stress, since it usually belongs to fundamental life decisions. It is necessary to emphasize that higher demands are put on students at university (regarding the extent of schoolwork, performance requirements or requirements for mastering the schoolwork) in contrast to high school. Říčan (2007) states that in this case, it is important to realize that the student himself voluntarily chose to study at university for a certain purpose.

László (2004) specifies concrete decision-making aspects of students in terms of motivation to study:

$\checkmark$ direct orientation on a subject field (obtaining new knowledge);

$\checkmark$ obtaining a suitable job (personality development, career growth, social status);

$\checkmark$ participation in social life (meeting new people, extracurricular activities);

$\checkmark$ escape from adults' responsibilities (not ideal situation at home, proving that you are independent).

There is a very wide range of aspects influencing the motivation of students who decide to study at university. Every individual is specific and has unique requirements. It is important to approach every person individually. Based on the results of our survey which we conducted on a sample of students at the Faculty of Social Sciences, University of Ss. Cyril and Methodius in Trnava (hereinafter referred to as FSS UCM), it was confirmed that students really are diverse. However, we can say with certainty that the aspects defined by László (2004) and subsequently by Newstead et al. (1996) precisely specify a general overview of the most important ones. Some students consider the time they spend at university as a space to look around and develop their personality. Other students know exactly what they want, and they perceive school as an opportunity to gain new knowledge and deepen already acquired knowledge. Subsequently, there is a group of individuals who perceive higher education as an opportunity to establish new relationships and implement their own matters, as they have more space to do it during their studies than during work. Last but not least, motivation may arise from not very favourable conditions at home, frequent quarrels with parents, a desire to prove independence, etc.

Students who have decided to study at university are introduced to a new environment and new people; they have to adapt and learn certain principles of behaviour. The university teaches them how to be more independent, mature, responsible and specialized in a certain field. The way students cope with all the new motives is individual. Some of them adapt quickly, others need more time. However, teachers' support is also very important (Danek, 2014).

To compare, we present a definition of motivational aspects influencing decision-making about studies from the perspective of Newstead et al. (1996): 
$\checkmark \quad$ to gain some time (individuals can decide on their future job, they do not have to work yet, they want to have fun);

$\checkmark$ better qualification (to gain an academic title, to have a well-paid job, to increase the social status in society);

$\checkmark$ personal development and potential (to have better control over life).

This division can also be considered very stimulating. Many young people do not know what kind of occupation would be ideal for them after graduation. Therefore, it is better to consider studying at university, as it can provide good perspective and qualification in a field. On the contrary, there are students who are exclusively interested in fun and social life that university can provide. Other students want a better qualification, or they wish for a job which they can apply for only after obtaining a relevant academic title.

Říčan (2007) gives a specific example, using which he points out an understanding of diversity of motivational factors. It is likely that a student graduating from high school who decides on whether to study at university will decide based on different criteria than a bachelor student who decides on whether to continue in his studies at a master's degree. It is important to keep in mind that the effectiveness of studies is affected by the speed and level of the adaptation process, compared to the previous period.

The findings we have obtained through our own examination of the process of motivation for higher education are summarized in the following statements and conclusions.

In terms of the main motives influencing the decision to enroll in a particular study programme, it is necessary to mention that students do not have to take entrance examinations and the faculty is accessible from the place of their permanent residence. This indicates that students have a certain preference for comfort. Recommendations from friends and acquaintances and an effort to obtain a relevant title also belong to significant motives influencing their decision. $20.7 \%$ of the respondents stated long-time interest in the field as one of the motives. Mass media and personal visit of the university during Open Day which is organized every year do not play an important role in the student's motivation.

During the studies, the respondents verify whether they have made a right decision in terms of their study programme. Approximately one half of all the respondents would decide to study the same programme at the same faculty and university, while, it is clear, that men have a stronger bond with the university than women. $22.1 \%$ of the respondents (mostly women) would rather study at a different university in Slovakia. It means that they would deal with the fulfilment of their ideas in an active way. Finally, $8.9 \%$ of the respondents would give up on higher education, as they would revoke their original decision and would not like to study at any university anymore.

What is important, is the fact that $75.6 \%$ of the respondents stated that their current study experiences have met their expectations. According to the respondents, the most common source of study problems is the organization of studies at university. This problem has been 
reported mainly among students of bachelor study programmes because the transform from high school to university is often problematic, as at university, there are different methods of learning and timetables used, as well as other criteria and frequency of examinations.

The overall success in the field of study as well as the formation of respondents' opinions can be affected by the way they spend their leisure time during the studies. It is evident that the respondents, as the representatives of young generation, do things in their leisure time more actively. The quantity, quality, semantics and structure of leisure time activities change relatively quickly in the development of society. Sport, trips to nature and hobbies dominate the active leisure time activities, while culture, activities on a computer and mobile phone dominate the passive leisure time activities.

During the studies, an idea of a working activity after successful graduation from university is being formed. Approximately one third of the respondents would like to be employed in the public sector, which corresponds with the professional orientation of the faculty. A significant part of bachelor students wants to continue in their studies at master's degree (82\%), and around 3\% of master students are interested in continuing in their studies at a doctoral degree. The respondents showed no interest in working in education or being employed in the private sector. A significant part of men would like to carry on a business $(26.3 \%)$.

In conclusion, although the influence of a family is not crucial for the respondents who are deciding about their university studies, these families can still play a role in respondents' decisions to work or carry on a business with regard to the location of their work, as many of them may have ties to their private property, in particular the property of parents or relatives. Many respondents expect a material and financial support from their parents when they start a practice, and they also see not inconsiderable opportunities for partial assistance from parents and relatives when it comes to upbringing and taking care of children. These are a few examples of psychosocial aspects of respondents' lives, where a number of interpersonal relationships are formed in its whole complexity in their workplace and the closest surroundings.

\section{Acknowlegment}

This work was funded by University of Ss Cyril and Metodius in Trnava, Slovak Republic, Europe.

This paper was created within the University of St. Cyril and Methodius FPPV project Motivačné aspekty rozhodovania pre vysokoškolské štúdium. Project registration number is FPPV-18-2021.

\section{References}


DANEK, 2014. Pedagogická dokumentácia na vysokej škole. [Evaluation documentation at the univerzsity] Trnava : Univerzita sv. Cyrila a Metoda, 2014. 128 p. ISBN 978-808105-614-7.

LÁSZLO, K. 2004. Motivácia vedukačnom prostredí. [Motivation in the educational environment] Banská Bystrica : Univerzita Mateja Bela, 2004. 90 p. ISBN 80-8055975-9.

NEWSTEAD, S. et al. Individual Differences in Student Cheating. Journal of Educational Psychology. Praha : Academia, 1996. P. 241. ISSN 125-0746.

ŘÍČAN, P. 2007. Psychologie osobnosti.[Psychology of personality] Praha : Grada Publishing, 2007. 208 p. ISBN 978-80-247-1174-4.

VYBÍHAL, V. - KUBÍČEK, J. 1974. Návrh metodiky stanovení počtu respondentů a délky pozorování při demografickém výzkumu. [Proposal of a metodology for determining the number of respondents and the length of observations in demographic research] Acta Univ. Agric., 10, p. 297. Brno, 1974, VŠZ, Czech republic 